\title{
Characterization of a Hydrophobic Amylase Inhibitor from Corn (Zea mays) Seeds with Activity Against Amylase from Fusarium verticillioides
}

\author{
Edson L. Z. Figueira, Elisa Y. Hirooka, Elizabeth Mendiola-Olaya, and Alejandro Blanco-Labra
}

First and second authors: Universidade Estadual de Londrina, Campus Universitário, Caixa Postal 6001, CEP 86051-990, Londrina-PR, Brazil; and third and fourth authors: Centro de Investigación y de Estudios Avanzados del IPN, Unidad Irapuato, Apdo. Postal 629, 36500 Irapuato-Gto, Mexico.

Accepted for publication 31 December 2002.

\begin{abstract}
Figueira, E. L. Z., Hirooka, E. Y., Mendiola-Olaya, E., and Blanco-Labra, A. 2003. Characterization of a hydrophobic amylase inhibitor from corn (Zea mays) seeds with activity against amylase from Fusarium verticillioides. Phytopathology 93:917-922.

A hydrophobic 19.7-kDa amylase inhibitor (AI) was purified from corn kernels by $95 \%$ ethanol extraction and anionic exchange chromatography. The AI has an isoelectric point of 3.6 and was very stable at different $\mathrm{pH}$ values and high temperatures, maintaining $47.6 \%$ activity after heating to $94^{\circ} \mathrm{C}$ for $60 \mathrm{~min}$. Amino acid analysis indicated high valine, leucine, glycine, alanine, and glutamic acid/glutamine content, and especially high valine content $(41.2 \mathrm{~mol} \%)$. This inhibitor is not a

glycoprotein. It required 30-min preincubation to maximize complex enzyme-inhibitor formation when the amylase from Fusarium verticillioides was tested. The optimal $\mathrm{pH}$ of interaction was 6.5. It showed broad-spectrum activity including the following amylases: human saliva, porcine pancreas, $F$. verticillioides, as well as those from some insects of agricultural importance (Acanthoscelides obtectus, Zabrotes subfasciatus, Sitophilus zeamais, and Prostephanus truncatus). This novel hydrophobic protein not only inhibited the amylase from $F$. verticillioides but also decreased the conidia germination. Thus, this protein represents an approach to decrease the production of fumonisin in corn, either by using it as a molecular marker to detect fungal resistance or through genetic engineering.
\end{abstract}

Fusarium verticillioides is the fungus most frequently found in corn kernels $(10,13)$. It is responsible for production of a group of structurally related metabolites known as fumonisins. A large number of reports on the occurrence of these mycotoxins in corn and corn-based foods and feeds have been published. They are associated with diseases at all stages of corn plant development, infecting the roots, stalk, and kernels (20). These toxins are a recurrent problem worldwide in corn, and so far, their postharvest elimination from corn kernels is not economically feasible. Therefore, efforts are presently focused on control strategies that prevent preharvest as well as postharvest contamination. Among these, the most desirable control strategy is based on the use of resistant corn, or possibly the use of genetically engineered plants that express antifungal proteins. Another possible approach could be based on the identification of naturally occurring components in corn that inhibit fumonisin synthesis as proposed by Munkvold and Desjardins (16).

The natural occurrence of $\alpha$-amylase inhibitors (AI) has been reported in a wide variety of plants since Chrzaszcz and Janicki detected the first AI in wheat in 1933 and 1934 (6). The research on corn AI started in the 1980s with the detection of a protein active against insect $\alpha$-amylase that was inactive against Aspergillus oryzae $\alpha$-amylase (2). Later, Mahoney et al. (14) and BlancoLabra et al. (1) characterized a $12-\mathrm{kDa}$ bifunctional protein active against insect $\alpha$-amylase (Tribolium castaneum and Callosobruchus maculatus) and also active against bovine and fungal protease (Aspergillus niger and Aspergillus fumigatus). These findings triggered interest in the study of these inhibitors as part of

Corresponding author: A. Blanco-Labra; E-mail address: ablanco@ira.cinvestav.mx

Publication no. P-2003-0611-01R

(C) 2003 The American Phytopathological Society the natural resistance in corn for the control of specific phytopathogens. Although, Figueira et al. (7) reported a corn inhibitor that inhibited $F$. verticillioides amylase in vitro, it did not have an effect when measured in the field against this fungus.

AIs have been reported to play important roles as part of plant defense mechanisms, particularly against attack by insects such as Sitophilus oryzae, Tenebrio molitor, T. confusum, and C. maculatus $(1,9,24)$. Advances have been made in expressing some of these inhibitors in different crops to provide increased resistance to specific insects $(12,15)$.

In this work, we describe the isolation and partial characterization of a new 19.7-kDa hydrophobic AI from corn (Zea mays L.) kernels. This protein inhibits the amylase activity and the conidia germination of $F$. verticillioides. It is also active against the amylase from some economically important insects. Therefore, it has potential to control both the production of mycotoxins and insect attack in important grain crops.

\section{MATERIALS AND METHODS}

Kernels of corn hybrid AG5011 harvested from the 1999 crop were used as the source of the AI and were provided by A. C. Gerage from the Agronomy Institute of Parana (Brazil). The kernels were dried in the field to $14 \%$ moisture content and stored at $-20^{\circ} \mathrm{C}$.

$\alpha$-Amylase from the mycotoxigenic fungus was obtained from $F$. verticillioides (previously known as $F$. moniliforme) strain $113 \mathrm{~F}$ cultures that were isolated from kernels involved in animal intoxications. The strain was maintained on potato dextrose agar at $4^{\circ} \mathrm{C}$. Crude amylase was obtained by growing the fungus in corn medium as described by Figueira and Hirooka (8). The activated fungal strain was inoculated into $480 \mathrm{ml}$ of corn medium, consisting of $2 \%$ ground corn in the supernatant of milky stage 
corn and incubated for 20 days at $25^{\circ} \mathrm{C}$. The culture medium was centrifuged at $5,000 \times g$ for $10 \mathrm{~min}$ at $4^{\circ} \mathrm{C}$ using the supernatant as the source of amylase.

Human salivary and pancreatic $\alpha$-amylases were obtained from Pharmacia Diagnostics AB (Upsala, Sweden) and swine pancreatic $\alpha$-amylase, barley $\alpha$-amylase, and $\beta$-amylase were obtained from Sigma Chemical Co. (St. Louis). Amylases from different insects were obtained according to the method of Blanco-Labra et al. (1). Insects were provided by the insectary at Cinvestav-Irapuato Unit (Mexico). Insect cultures of Prostephanus truncatus, S. cerealela, and $S$. zeamais were maintained on whole maize seeds, whereas $T$. castaneum was grown on wheat flour. C. maculatus cultures were maintained on whole chickpea seeds, and Zabrotes subfasciatus and Acanthoscelides obtectus cultures were grown on whole navy beans. All cultures were maintained in growth chambers at $28^{\circ} \mathrm{C}$ with 65 to $75 \%$ relative humidity. For amylase extraction, the lar-

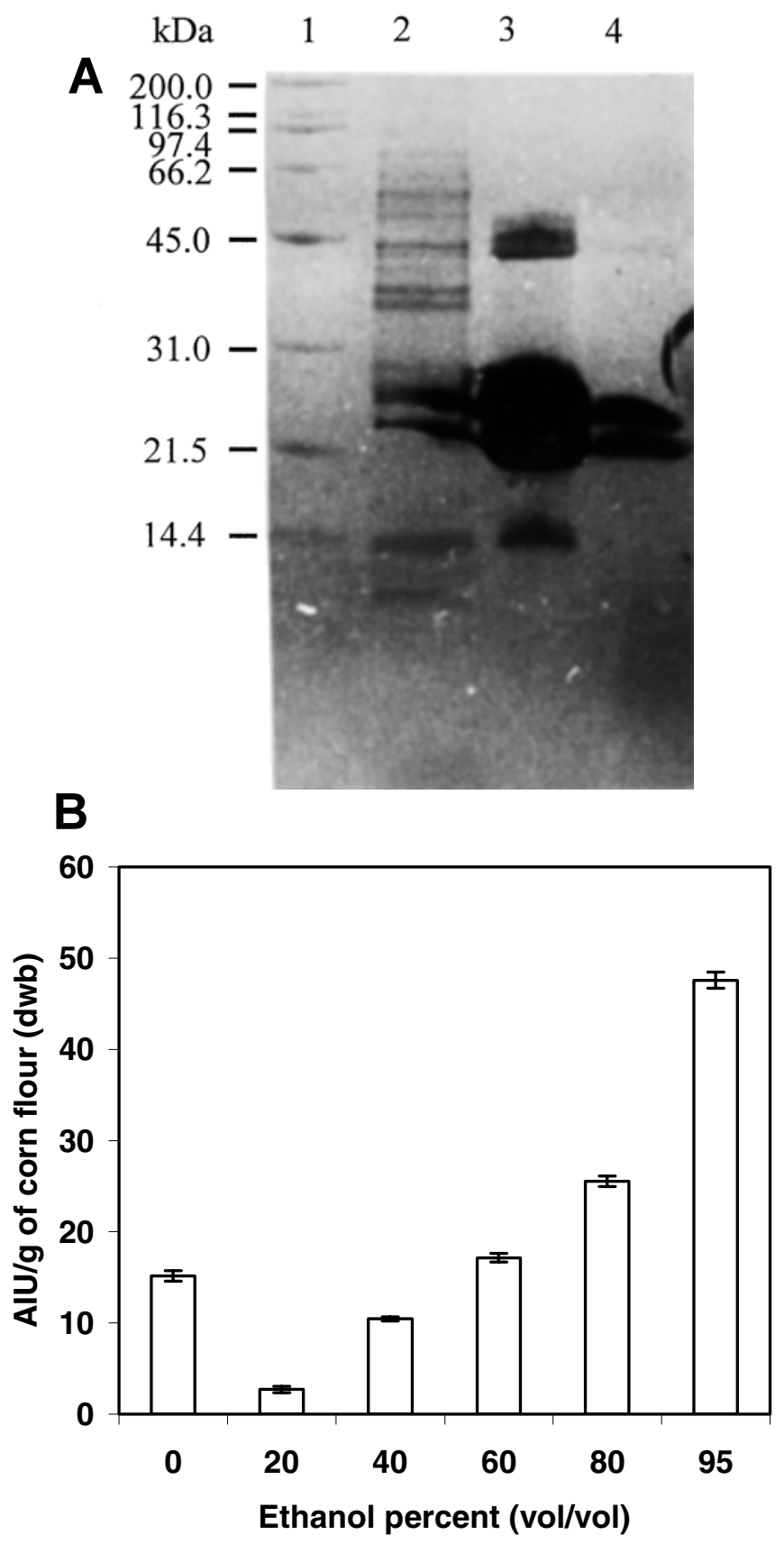

Fig. 1. Extraction of amylase inhibitor (AI) using different ethanol concentrations. A, Electrophoresis of extraction products: lane 1, molecular weight standards; lane 2, 0\% ethanol; lane 3,60\% ethanol; and lane 4, 95\% ethanol. B, Total AI activity extracted. dwb = dry weight basis. vae of the corresponding insects were homogenized with different buffer solutions in a 1:5 (wt/vol) ratio. In the case of $P$. truncatus $\alpha$-amylase, the extraction was done in a solution of $0.1 \mathrm{M} \mathrm{NaCl}$ and $40 \mathrm{mM}$ succinate, $\mathrm{pH}$ 6.5. The amylases from $S$. zeamais, $T$. castaneum, Z. subfasciatus, C. maculatus, and A. obtectus were extracted with $0.2 \mathrm{M}$ succinate buffer, $\mathrm{pH}$ 4.5. The suspensions were centrifuged at $10,000 \times g$ for $10 \mathrm{~min}$ at $4^{\circ} \mathrm{C}$, and the supernatants were used as the source of $\alpha$-amylase. $\alpha$-Amylases from corn and rice were extracted in a solution of $0.01 \mathrm{M} \mathrm{CaCl}_{2}$ and $0.1 \mathrm{M} \mathrm{NaCl}$ from germinated seeds at 5 and 3 days, respectively.

AI assay. Amylase activity was analyzed by the iodometric method (23) modified to a micro-method for microplate assay. One unit of amylase activity (AU) was defined as the amount of enzyme that hydrolized $0.1 \mathrm{mg}$ of starch in $10 \mathrm{~min}$ at $4^{\circ} \mathrm{C}$, when $5.0 \mathrm{mg}$ of starch was present. One unit of AI activity (UI) was defined as the amount of protein that inhibited $1 \mathrm{AU}$ of fungal amylase. The AI activity was measured by preincubating the AI with the amylase ( 0.2 units of amylase activity) for $30 \mathrm{~min}$ at $25^{\circ} \mathrm{C}$. The residual amylase activity was measured after the substrate was added and the reaction was left to proceed for $60 \mathrm{~min}$ at $25^{\circ} \mathrm{C}$. A starch control without amylase was used in each test.

One unit of AI was defined as the amount of protein that inhibited 1 unit of amylase activity/AU under the assay conditions described. One unit of amylase activity/AU was defined as the amount of enzyme that hydrolyzed $0.1 \mathrm{mg}$ of starch in $60 \mathrm{~min}$ at $25^{\circ} \mathrm{C}$.

AI extraction. In order to optimize the AI extraction, several ethanol concentrations were tested $(0,20,40,60,80$, and 95\%). Ninety-five percent ethanol provided the best results. Finely ground corn kernels (48 mesh in a mill [Model A10, Janke \& Kunkel, West Germany]) were suspended in each solution $(1: 5, \mathrm{wt} / \mathrm{vol})$ and continuously stirred in an orbital shaker $(150 \mathrm{rpm})$ for $2 \mathrm{~h}$ at room temperature. The supernatant was separated by centrifugation $\left(30,000 \times g\right.$ for $20 \mathrm{~min}$ at $\left.4^{\circ} \mathrm{C}\right)$, and the activity was determined.

AI purification. Finely ground corn kernels were extracted with $95 \%$ ethanol $(1: 5, \mathrm{wt} / \mathrm{vol})$ as previously described, and the supernatant was separated by centrifugation $(30,000 \times g$ for $20 \mathrm{~min}$ at $4^{\circ} \mathrm{C}$ ) and dried in a speed vacuum. The pellet was dissolved in $0.01 \mathrm{M}$ ammonium bicarbonate containing $1 \%$ Triton $\mathrm{X}-100$ and applied to an Econo-Pac Q cartridge, $1.0 \times 5.0 \mathrm{~cm}$ (Bio-Rad Laboratories, Hercules, CA), equilibrated with the same solution, and eluted with a salt gradient from 0 to $0.25 \mathrm{M} \mathrm{NaCl}$ in $0.01 \mathrm{M}$ ammonium bicarbonate containing 1\% Triton X-100 over $90 \mathrm{~min}$ at a flow rate of $1 \mathrm{ml} / \mathrm{min}$. Two milliliter fractions were collected. The active fractions eluted from this column were pooled and stored at $-20^{\circ} \mathrm{C}$.

Preincubation time effect. Constant amounts $(1.3 \mu \mathrm{g})$ of AI were preincubated with $0.05 \mathrm{M} \mathrm{KH}_{2} \mathrm{PO}_{4}-\mathrm{NaOH}$ buffer $(\mathrm{pH}$ 6.7) for $0,5,10,15,30,45,60$, and $120 \mathrm{~min}$ at $25^{\circ} \mathrm{C}$ containing fixed amounts of amylase from $F$. verticillioides prior to addition of substrate. The remaining amylase activity was determined.

Thermal stability. Constant amounts $(1.3 \mu \mathrm{g})$ of AI were heated in $0.05 \mathrm{M} \mathrm{KH}_{2} \mathrm{PO}_{4}-\mathrm{NaOH}$ buffer $(\mathrm{pH}$ 6.7) for $0,5,10,15$, 30,45 , and $60 \mathrm{~min}$ at 50,70 , and $94^{\circ} \mathrm{C}$. The samples were immediately cooled and preincubated for $30 \mathrm{~min}$ with the amylase from $F$. verticillioides at $25^{\circ} \mathrm{C}$, and the remaining amylase activity was determined.

TABLE 1. Purification of amylase inhibitor from corn kernels

\begin{tabular}{lccc}
\hline Procedure & $\begin{array}{c}\text { Specific activity } \\
\text { (AIU/mg of protein) }\end{array}$ & $\begin{array}{c}\text { Yield } \\
(\%)\end{array}$ & $\begin{array}{c}\text { Purification } \\
\text { (fold) }\end{array}$ \\
\hline $\begin{array}{l}\text { Crude extract in 95\% ethanol } \\
\begin{array}{l}\text { Extraction in 0.01 M } \\
\text { ammonium bicarbonate }\end{array}\end{array}$ & 8.9 & 100.0 & 1.0 \\
$\begin{array}{l}\text { containing 1\% Triton X-100 } \\
\text { Anion exchange (Q-Sepharose) } \\
\text { chromatography }\end{array}$ & 41.8 & 74.8 & 4.7 \\
\hline
\end{tabular}


pH effect on AI activity. To determine the effect of $\mathrm{pH}$ on the inhibition of the $F$. verticillioides amylase, AI $(1.3 \mu \mathrm{g})$ activity was measured at $\mathrm{pHs} 4.0,5.0,6.0,6.5,7.0,8.0$, and 9.0 using the following $0.05 \mathrm{M}$ buffers: sodium acetate (pHs 4.0 and 5.0); sodium phosphate (pHs 6.0, 6.5, and 7.0); and Tris- $\mathrm{HCl}$ (pHs 8.0 and 9.0). The AI and the enzyme concentrations were kept constant $(0.2 \mathrm{UI})$. The AI and the amylase were preincubated together at each $\mathrm{pH}$ for $30 \mathrm{~min}$ at $25^{\circ} \mathrm{C}$, and the remaining amylase activity was determined.

pH stability. The effect of $\mathrm{pH}$ on AI stability was measured at pHs 4.0, 5.0, 6.0, 6.5, 7.0, 8.0, and 9.0 using the same buffers as described previously. The AI $(1.3 \mu \mathrm{g})$ was incubated for $16 \mathrm{~h}$ at $4^{\circ} \mathrm{C}$, the samples were adjusted to $\mathrm{pH} 6.7$, and the residual activity was determined.

Molecular weight determination. The apparent molecular weight of the purified AI was measured by sodium dodecyl sulfatepolyacrylamide gel electrophoresis (SDS-PAGE) according to the method of Schägger and von Jagow (19), using 4\% acrylamide for the stacking gel and 13\% for the separating gel. Molecular weight standards (Bio-Rad) were run in adjacent lanes, and the gels were silver-stained according to the method of Bloom et al. (4).

Isoelectric point determination. The AI isoelectric point was measured in a Rotofor Cell (Bio-Rad) using ampholytes and $\mathrm{pH}$ ranging from 3.0 to 10.0 . Focusing was carried out at $15 \mathrm{~W}$ constant power for $4 \mathrm{~h}$ at $4^{\circ} \mathrm{C}$. Twenty fractions were collected for $\mathrm{pH}$ and $\mathrm{AI}$ activity determination.

Specificity. The specificity of the AI was evaluated against amylase extracts from $F$. verticillioides, human saliva and pancreas, swine pancreas, and germinated corn, rice, and barley (in barley $\alpha$-amylase was also determined), and from insects such as S. zeamais, T. castaneum, Z. subfasciatus, A. obtectus, $P$. truncatus, and $S$. cerealela. The AI (1.3 $\mu \mathrm{g})$ with the corresponding amylase was preincubated for $30 \mathrm{~min}$ at room temperature in $0.05 \mathrm{M}$ sodium phosphate buffer, $\mathrm{pH} 7.0$, before the inhibitory activity was measured.

Carbohydrate. The possible presence of carbohydrate in AI was determined by SDS-PAGE following the method of Schägger and von Jagow (19). Acrylamide concentrations were $4 \%$ for the stacking gel and $10 \%$ for the separating gel, and the gel was stained with Schiff reagent (periodic acid-Schiff).

Dilution factor. The possible presence of molecular aggregates was determined by a dilution experiment in which the AI was di- luted 1:2, 1:4, 1:8, and 1:10. The specific AI activity was determined in the standard solution, and in each dilution, with the amount of AI constant $(1.3 \mu \mathrm{g})$ throughout the assay.

Amino acid analysis. Amino acid analysis of the purified AI was determined by reverse-phase high-performance liquid chromatography. A $260-\mu g$ sample was hydrolyzed under vacuum with $200 \mu \mathrm{l}$ of $6 \mathrm{~N} \mathrm{HCl}$ and $1.0 \%$ distilled phenol at $105^{\circ} \mathrm{C}$ in a sealed tube for $24 \mathrm{~h}$. The hydrolyzed sample was dried and derivatized with phenyl isothiocyanate, dried, and solubilized in $0.005 \mathrm{M}$ phosphate buffer, $\mathrm{pH} 7.4$, and methanol $(8: 2, \mathrm{vol} / \mathrm{vol})$, and $4 \mu \mathrm{l}$ was analyzed on a C-18 Pico-Tag column. Data were integrated using an integrator (Model 19-740; Waters Chromatography, Millipore Corp., Bedford, MA). Cysteine was determined according to Thannhauser et al. (22) as modified by Chan and Wasserman (5).

Fungal growth assay. Growth medium $(1 \mathrm{ml})$ composed of $1 \%$ starch and $0.13 \%$ tryptone, containing $0,25,50,100$, and $200 \mu \mathrm{g} / \mathrm{ml}$ of $\mathrm{AI}$, was placed in a sterile tube. F. verticillioides $\left(1.6 \times 10^{6}\right.$ conidia) was added to the medium to test for inhibition

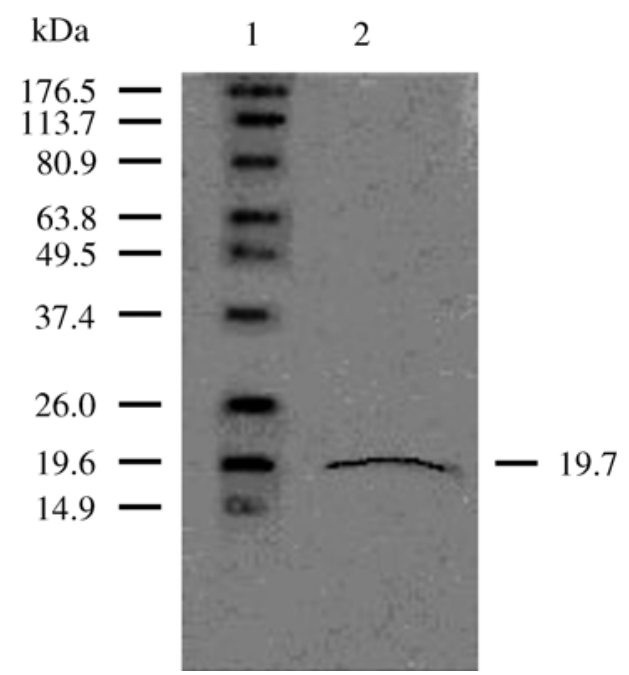

Fig. 3. Sodium dodecyl sulfate-polyacrylamide gel electrophoresis of the amylase inhibitor (AI) active peak from ion exchange chromatography. Lane 1, molecular weight markers; and lane 2, AI.
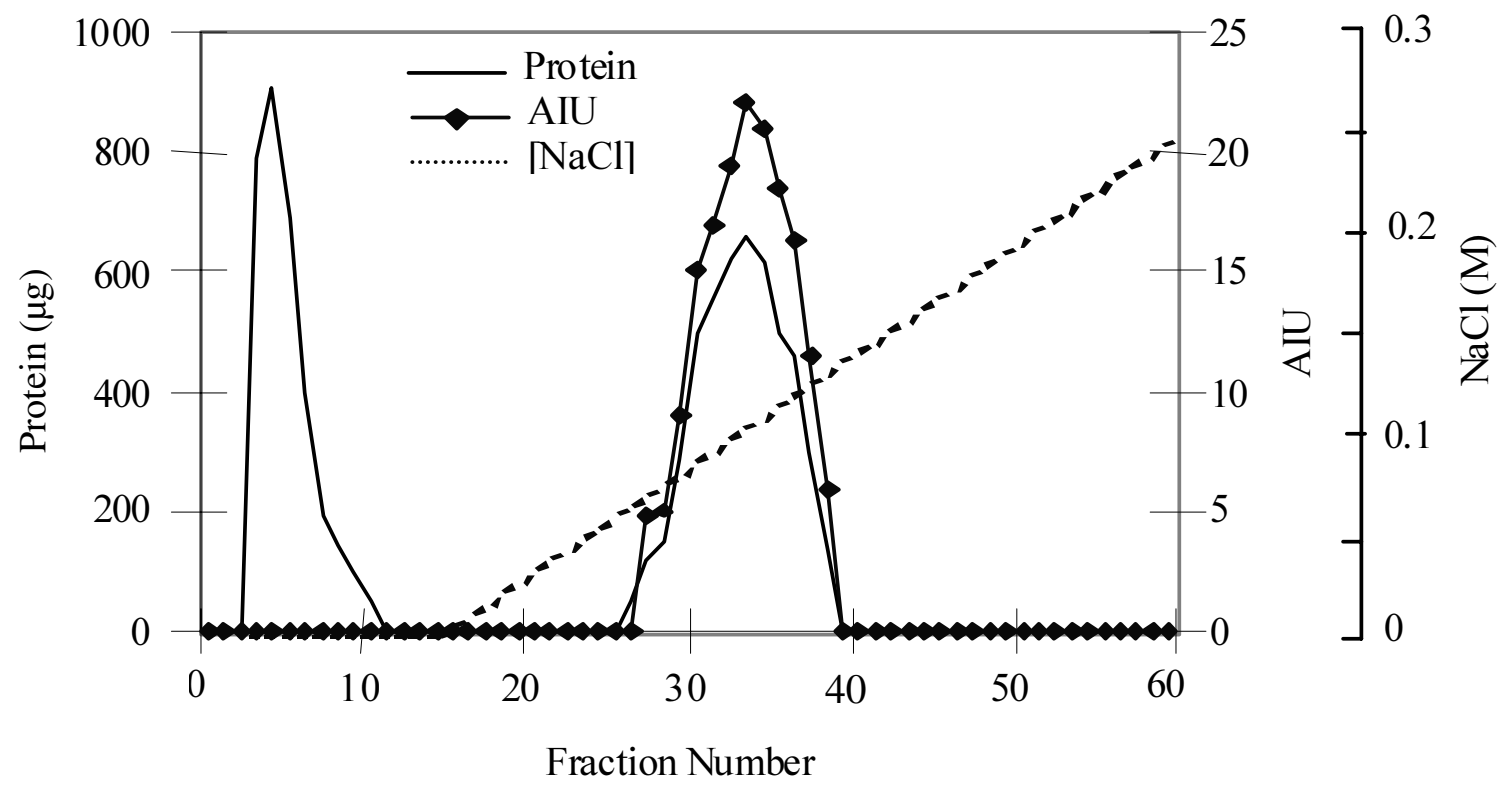

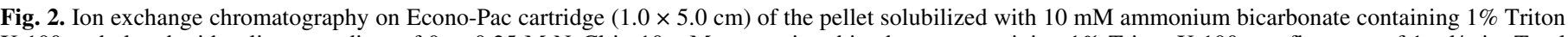

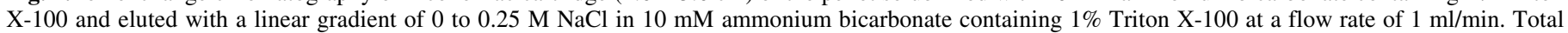
time for elution was $90 \mathrm{~min}$. 
of conidial germination and hyphal growth. Germination data were collected from three repetitions comprising 100 conidia each. Hyphal growth data represent three repetitions of 40 determinations each.

Protein assay. Protein was determined by the bicinchoninic acid procedure (21). Bovine serum albumin was used as the standard protein.

\section{RESULTS}

With regard to the extraction procedure, increasing the percentage of ethanol up to $95 \%$ during the extraction, the amount

TABLE 2. Amino acid composition of the purified amylase inhibitor (AI) and its nutritional value ${ }^{\mathrm{a}}$

\begin{tabular}{|c|c|c|c|c|c|}
\hline \multirow[b]{2}{*}{ Amino acid } & \multicolumn{2}{|c|}{ Mol\% } & \multirow[b]{2}{*}{ Amino acid } & \multicolumn{2}{|c|}{$\mathrm{Mol} \%$} \\
\hline & AI & FAO/WHO & & AI & FAO/WHO \\
\hline Asx & 1.4 & $\ldots$ & Val & 41.2 & 4.2 \\
\hline Glx & 7.0 & $\ldots$ & Met & 1.7 & $\ldots$ \\
\hline Ser & 3.4 & $\ldots$ & Cys & 1.0 & $\ldots$ \\
\hline Gly & 7.1 & $\ldots$ & Met+Cys & 2.7 & 3.0 \\
\hline His & 2.1 & $\ldots$ & Ile & 2.3 & 3.5 \\
\hline Arg & 0.7 & $\ldots$ & Leu & 9.3 & 6.2 \\
\hline Thr & 2.6 & 3.9 & Phe & 3.7 & $\ldots$ \\
\hline Ala & 7.1 & $\ldots$ & Phe+Tyr & 5.3 & 4.0 \\
\hline Pro & 7.1 & $\ldots$ & Lys & 0.7 & 4.3 \\
\hline Tyr & 1.6 & $\ldots$ & Trp & - & 0.5 \\
\hline
\end{tabular}

a Nutritional values were calculated from the Food and Agricultural Organization and the World Health Organization (1973). - indicates not determined.

TABLE 3. Thermostability of the amylase inhibitor ${ }^{\mathrm{a}}$

\begin{tabular}{lccr}
\hline & \multicolumn{3}{c}{ Temperature $\left({ }^{\circ} \mathrm{C}\right)$} \\
\cline { 2 - 4 } Time $(\min )$ & 50 & 70 & \multicolumn{1}{c}{94} \\
\hline 15 & $86.7 \pm 1.4$ & $104.6 \pm 6.9$ & $107.2 \pm 2.9$ \\
30 & $90.3 \pm 3.9$ & $103.0 \pm 1.6$ & $135.8 \pm 4.3$ \\
60 & $92.7 \pm 3.0$ & $89.6 \pm 9.0$ & $47.6 \pm 4.6$ \\
\hline
\end{tabular}

a Numbers indicate percent inhibition activity compared with no heated protein \pm standard deviations. Samples were heated for 15, 30, and $60 \mathrm{~min}$ at the indicated temperature, immediately cooled, and the activity was determined at $25^{\circ} \mathrm{C}$.

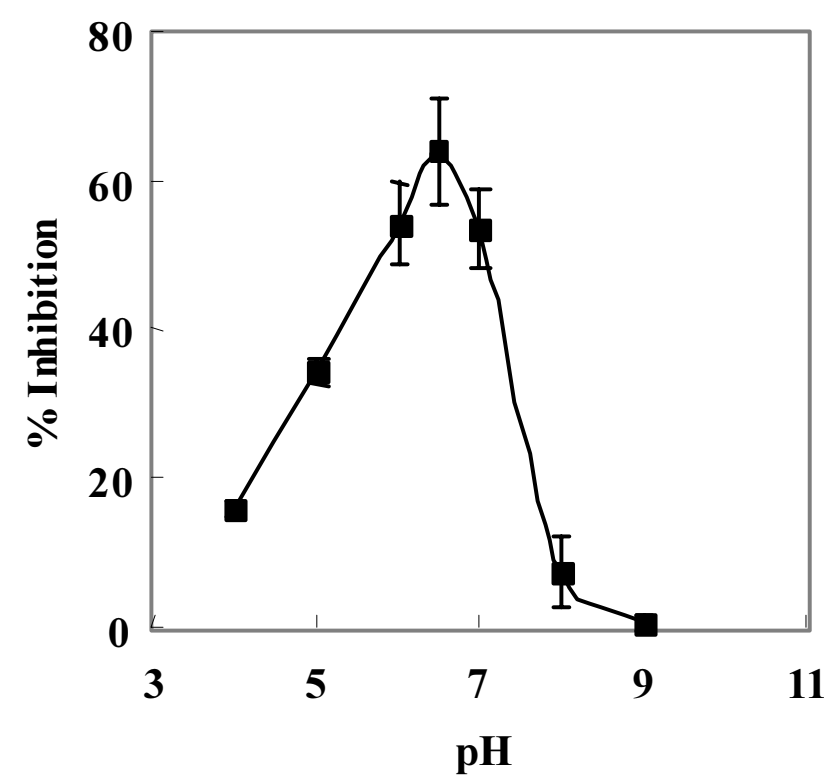

Fig. 4. Effect of $\mathrm{pH}$ on amylase inhibitor (AI) activity. Purified AI (1.3 $\mu \mathrm{g})$ and amylase from Fusarium verticillioides (0.2 AU) were used. and selectivity of the AI extraction, as shown by SDS-PAGE analysis under reducing conditions, improved steadily (Fig. 1).

The overall results of the purification procedure are shown in Table 1. In the typical experiment, $100 \mathrm{~g}$ of corn flour was extracted with $500 \mathrm{ml}$ of $95 \%$ ethanol (crude extract), yielding approximately $0.58 \mathrm{~g}$ of protein. After solvent elimination in a speed vacuum, the pellet was solubilized in $0.01 \mathrm{M}$ ammonium bicarbonate containing $1 \%$ Triton X-100, obtaining a $74.7 \%$ AI recovery with 4.7 -fold purification. The protein extract was then applied to an anion exchange chromatography column. The AI was eluted with a $\mathrm{NaCl}$ linear gradient in $0.01 \mathrm{M}$ ammonium bicarbonate containing $1 \%$ Triton $\mathrm{X}-100$. The AI was eluted as a single nonsymmetric peak (Fig. 2) with a final yield of $56.4 \%$ of the total activity originally present and purification of 14 times (Table 1).

The active fractions (peak 2) obtained after ion-exchange chromatography were pooled and concentrated using an ultrafiltration cell with a $10-\mathrm{kDa}$ molecular weight exclusion membrane, and the apparent molecular weight determined by SDS-PAGE under reducing conditions. The purified AI gave a single protein band, with an apparent molecular weight of $19.7 \mathrm{kDa}$ (Fig. 3). The negative stain for carbohydrates after SDS-PAGE indicated that the AI is not a glycoprotein (data not shown).

The isoelectric point, determined by a Rotofor Cell system (Bio-Rad) with $\mathrm{pH}$ ranging from 3.0 to 10.0, gave a $\mathrm{pI}$ of 3.6. When a dilution factor assay for aggregate molecular detection was used (the protein was subjected to serial dilution with the

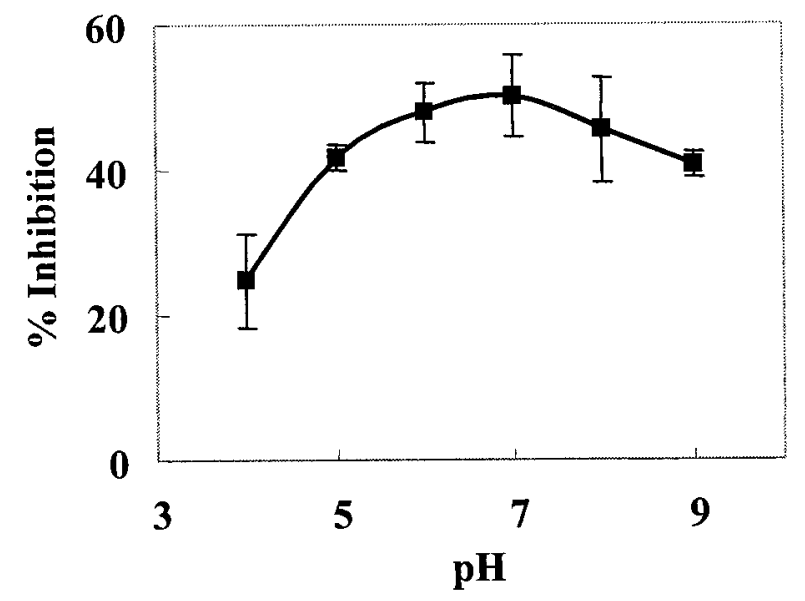

Fig. 5. Effect of $\mathrm{pH}$ on the stability of the purified amylase inhibitor (AI). Constant amounts of the inhibitor $(1.3 \mu \mathrm{g})$ and Fusarium verticillioides amylase $(0.2 \mathrm{AU})$ were used. The AI was incubated at $4{ }^{\circ} \mathrm{C}$ for $16 \mathrm{~h}$ at each $\mathrm{pH}$, and activity was measured at $\mathrm{pH}$ 6.7.

TABLE 4. Amylase inhibitor (AI) activity measured against amylases from different sources

\begin{tabular}{lc}
\hline Amylase source & Specific activity (AIU/mg of protein) $^{\mathrm{a}}$ \\
\hline Human saliva & $24.4 \pm 1.2$ \\
Human pancreas & - \\
Swine pancreas & $126.4 \pm 2.5$ \\
Fusarium verticillioides & $36.9 \pm 7.0$ \\
Acanthoscelides obtectus & $132.6 \pm 1.2$ \\
Zabrotes subfasciatus & $62.1 \pm 0.4$ \\
Tribolium castaneum & - \\
Sitophilus cerealela & - \\
Sitophilus zeamais & $93.1 \pm 1.3$ \\
Prostephanus truncatus & $58.8 \pm 1.6$ \\
Germinated corn & $11.9 \pm 1.6$ \\
Germinated rice & - \\
Barley $\alpha$-amylase & $109.7 \pm 1.8$ \\
Barley $\beta$-amylase & - \\
\hline
\end{tabular}

${ }^{\mathrm{a}}$ Means $\pm \mathrm{SD} ; n=3 ;-$ indicates no activity detected. 
total amount of protein remaining constant), the specific activity in all dilutions remained constant. Therefore, it was concluded that no molecular aggregates formed.

The AI amino acid composition (Table 2) showed a highly hydrophobic protein with $63.6 \mathrm{~mol} \%$ of hydrophobic amino acids and a very high valine concentration $(41.2 \mathrm{~mol} \%)$. In terms of nutritional value according to the Food and Agricultural Organization and the World Health Organization (1973), this AI showed low levels of the essential amino acids (lysine, threonine, cysteine plus methionine, and isoleucine) but exceptionally high levels of valine, leucine, and phenylalanine plus tyrosine.

The required preincubation time for formation of the enzymeinhibitor complex was $30 \mathrm{~min}$. The thermostability data (Table 3) indicated a relatively stable protein that was stable up to $100^{\circ} \mathrm{C}$ for $30 \mathrm{~min}$, maintaining almost half of the original activity.

When the effect of $\mathrm{pH}$ on AI activity was measured, it showed a maximum at $\mathrm{pH} 6.5$ (Fig. 4) that decreased at lower and higher $\mathrm{pH}$ values. The stability determination of $\mathrm{AI}$ at different $\mathrm{pH}$ values indicated maximal stability at neutral $\mathrm{pH}$ (Fig. 5).

The AI showed a broad spectrum of amylase inhibition, inhibiting the fungal amylase from $F$. verticillioides, and it inhibited amylases from the important insects of A. obtectus, Z. subfasciatus, $S$. zeamais, and $P$. truncatus, but it had no effect on the amylase activities from $T$. castaneum and $S$. cerealela. Amylases from human saliva and swine pancreas were also inhibited, but human pancreatic amylase was not. Amylases from germinating seed of rice and $\alpha$-amylase from barley were not inhibited, whereas $\alpha$-amylases from germinating corn and barley seeds were inhibited (Table 4).

Another important characteristic of this protein was the inhibition of fungal conidial germination. When conidia of $F$. verticillioides were incubated with 10, 25, 50, 100, and $200 \mu \mathrm{g} / \mathrm{ml}$ of AI, germination was reduced $100 \%$ after $12 \mathrm{~h}$ at an AI concentration of $50 \mu \mathrm{g} / \mathrm{ml}$ (Fig. 6).

\section{DISCUSSION}

The present work describes the purification and characterization of the ethanol soluble AI present in a $95 \%$ alcoholic extract of corn kernels. The purified AI showed some differences compared with other previously reported AIs. Among the differences is its high hydrophobicity, which explains its solubility in ethanol. Most of the AIs studied are water soluble (albumin-like inhibitors), some others are globulin-type proteins, which are extracted with $\mathrm{NaCl}$ solutions and dilute acid solutions. However, there are a few

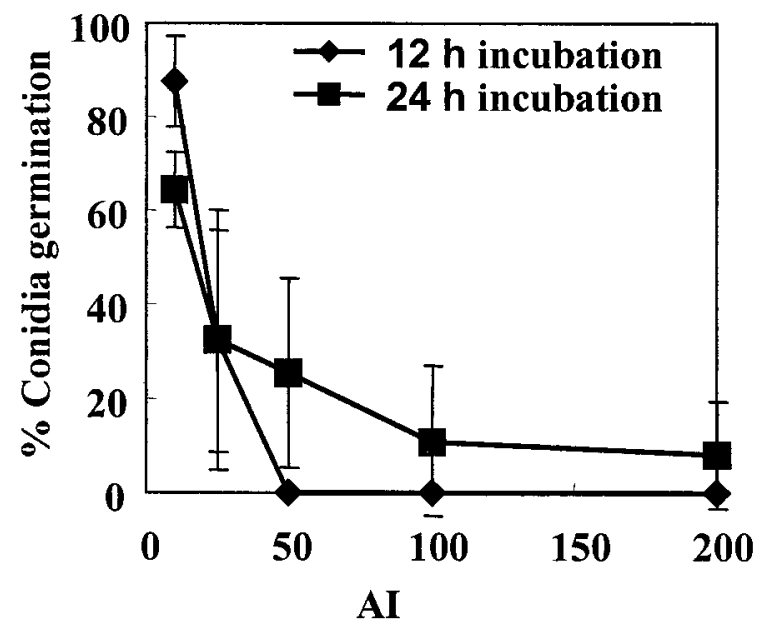

Fig. 6. Conidial germination at different amylase inhibitor (AI) concentrations at $25^{\circ} \mathrm{C}$. Each test had $1.6 \times 10^{6}$ conidia in a medium composed of $1 \%$ starch and $0.13 \%$ tryptone.
AIs that are extracted with aqueous alcohols, particularly 70 to $80 \%$ ethanol, such as some hydrophobic cereal storage proteins including several protease and AIs (18).

According to Osborne (17), based on the extraction procedure, this new AI would be classified as a prolamine. In corn, zein is the most important maize storage protein. This AI and these types of proteins are generally poor in basic amino acids, as are most of the zein proteins. AI also is poor in some essential amino acids (tryptophan, lysine, and threonine) but very rich in valine, leucine, and phenylalanine plus tyrosine.

The pI of this AI is similar to those reported from beans. However, unlike those found in common beans and tepary beans, this $\mathrm{AI}$ is not a glycoprotein $(3,11)$. The optimal $\mathrm{pH}$ of $6.5 \mathrm{de}-$ creased at higher and lower $\mathrm{pH}$ values.

This AI showed a broad spectrum of amylase inhibition; high inhibition on the fungal amylase from $F$. verticillioides and on amylases from some agriculturally important insects. In addition, this AI inhibited the germination of $F$. verticillioides conidia in vitro. Perhaps the most promising aspect for this AI is that it inhibits the amylase activity and conidial germination of the most important pathogen of corn, which also affects human and animal health. In addition, this inhibitor did not affect human pancreatic amylase, and it showed low inhibition on the amylase produced during corn germination. Therefore, this AI might be a useful molecular marker in the search for $F$. verticillioides resistance in corn.

Considering that an AI from common bean has been successfully expressed in pea (Pisum sativum) and in azuki bean, resulting in a pea with increased resistance to attack by Bruchus pisorum, and in azuki bean with increased resistance to $C$. chinensis, $C$. maculatus, and $C$. analis $(12,15)$, one should consider this AI a protein with good potential for its expression in other plants to increase resistance to specific pathogens and insects.

In summary, this AI shows interesting properties in vitro that could be of interest, particularly for its possible effect on the control of $F$. verticillioides and a decrease in fumonisin production. The broad spectrum of AI inhibition of insect amylases is interesting for its possible participation in the defense of grains against numerous insects of agricultural importance. However, there are several questions to be answered. Does this AI function in vivo as part of the defense mechanism of the plant? Where is it located inside the mature dry grain? Finally, if this inhibitor works in vivo, would this defense be sustained in time or would the fungus or insect develop resistance? These questions need to be answered if a protein is to be considered for developing a program to increase resistance to a specific fungus or insect.

\section{ACKNOWLEDGMENTS}

This work was financed by the National Council of Scientific and Technological Development-CNPq (Brazil) and 0003 CONCYTEG/ CONACYT-079 (Mexico). We thank the National Council of Scientific and Technological Development-CNPq for a doctoral fellowship to E. L. Z. Figueira (Process 144787/1998-9) and for a research productivity fellowship to E. Y. Hirooka and the CAPES Foundation (Brazil) for a doctoral sandwich fellowship to E. L. Z. Figueira (Process BEX0119/01-6).

\section{LITERATURE CITED}

1. Blanco-Labra, A., Chagolla-Lopez, A., Martínez-Gallardo, N., and ValdesRodriguez, S. 1995. Further characterization of the $12 \mathrm{kDa}$ protease/ alpha-amylase inhibitor present in maize seeds. J. Food Biochem. 19:27-41.

2. Blanco-Labra, A., and Iturbe-Chiñas, F. A. 1981. Purification and characterization of an $\alpha$-amylase inhibitor from maize (Zea maize). J. Food Biochem. 5:1-17.

3. Blanco-Labra, A., Sandoval-Cardoso, L., Mendiola-Olaya, E., ValdésRodríguez, S., and López, M. G. 1996. Purification and characterization of a glycoprotein $\alpha$-amylase inhibitor from tepary bean seeds (Phaseolus acutifolius A. Gray). J. Plant Physiol. 149:650-656.

4. Bloom, H., Beier, H., and Gross, H. S. 1987. Improved silver staining of 
the plant protein, RNA and DNA in polyacrylamide gels. Electrophoresis 8:93-99.

5. Chan, K. Y., and Wasserman, B. P. 1993. Direct colorimetric assay of free thiol groups and disulfide bonds in suspension of solubilized and particulated cereal proteins. Cereal Chem. 78:22-26.

6. Chrzaszcz, T., and Janicki, J. 1934. The inactivation of animal amylase by plant paralysers and the presence of inactivating substances in solutions of animal amylase. Biochem. J. 28:296-304.

7. Figueira, E. L. Z., Blanco-Labra, A., Gerage, A. C., Ono, E. Y. S., Mendiola-Olaya, E., Ueno, Y., and Hirooka, E. Y. 2003. New amylase inhibitor present in corn seeds active in vitro against amylase from Fusarium verticillioides. Plant Dis. 87:233-240.

8. Figueira, E. L. Z., and Hirooka, E. Y. 2000. Culture medium for amylase production by toxigenic fungi. Braz. Arch. Biol. Technol. 43:461-467.

9. Gatehouse, A., Fenton, K. A., Jepson, I., and Pavey, D. J. 1986. The effects of alpha-amylase inhibitors on insect storage pests: Inhibition of alpha-amylase in vitro and effects on development in vivo. J. Sci. Food Agric. 37:727-734.

10. González, H. H. L., Resnik, S. L., Boca, R. T., and Marasas, W. F. O. 1995. Mycoflora of Argentinean corn harvested in the main production area in 1990. Mycopathologia 130:29-36.

11. Ho, M. F., Yin, X., Filho, F. F., Lajolo, F., and Whitaker, J. R. 1994. Naturally occurring $\alpha$-amylase inhibitors: Structure/function relationships. Chapter 5 in: Protein Structure Function Relationships in Foods. R. Y. Yada, R. L. Jackman, and J. L. Smith, eds. Blackie Academic \& Professional, London.

12. Ishimoto, M., Sato, T., Chrispeels, M. J., and Kitamura, K. 1996. Bruchid resistance of transgenic azuki bean expressing seed $\alpha$-amylase inhibitor of common bean. Entomol. Exp. Appl. 79:309-315.

13. Kedera, C. J., Plattner, R. D., and Desjardins, A. E. 1999. Incidence of Fusarium spp. and levels of fumonisin $\mathrm{B}_{1}$ in maize in western Kenya. Appl. Environ. Microbiol. 65:41-44.

14. Mahoney, W. C., Hermodson, M. A., Jones, B., Powers, D. D., Corfman, R. S., and Reeck, G. R. 1984. Amino acid sequence and secondary structural analysis of the corn inhibitor of trypsin and activated Hageman
Factor. J. Biol. Chem. 259:8412-8416.

15. Morton, R. L., Schoeder, H. E., Bateman, K. S., Chrispeels, M. J., and Armstrong, E. 2000. Bean $\alpha$-amylase inhibitor 1 in transgenic peas (Pisum sativum) provides complete protection from pea weevil (Bruchus pisorum) under field conditions. Proc. Natl. Acad. Sci. USA 97:38203825.

16. Munkvold, G. P., and Desjardins, A. E. 1997. Fumonisins in maize, can we reduce their occurrence? Plant Dis. 81:556-565.

17. Osborne, T. B. 1924. The Vegetable Proteins. Longmans, Green \& Co., London.

18. Richardson, M. 1991. Seed storage proteins-The enzyme inhibitors. Chapter 10 in: Methods in Plant Biochemistry. L. Rogers, ed. Academic Press, New York.

19. Schägger, H., and von Jagow, G. 1987. Tricine-sodium dodecyl sulfatepolyacrylamide gel electrophoresis for the separation of proteins in the range from 1 to $100 \mathrm{kDa}$. Anal. Biochem. 166:368-379.

20. Shephard, G. S., Thiel, P. G., Stockenstrom, S., and Sydenham, E. W. 1996. Worldwide survey of fumonisin contamination of corn and cornbased products. J. AOAC Intern. 79:671-687.

21. Smith, P. K., Krohn, R. I., Hermanson, G. T., Mallia, A. K., Gartner, F. H., Provenzano, M. D., Fujimoto, E. K., Goeke, N. M., Olson, B. J., and Klenk, D. C. 1985. Measurement of protein using bicinchoninic acid. Anal. Biochem. 150:76-85.

22. Thannhauser, T. W., Konishi, Y., and Scheraga, H. A. 1987. Analysis for disulfite bonds in peptides and proteins. Methods Enzymol. 143:115119 .

23. Wilson, J. J., and Ingledew, W. M. 1982. Isolation and characterization of Schwanniomyces alluvius amylolytic enzymes. Appl. Environ. Microbiol. 44:301-307.

24. Xavier-Filho, J., Campos, F. A. P., Ary, M. B., Silva, C. P., Carvalho, M. M. M., Macedo, M. L. R., Lemos, F. J. A., and Grant, G. 1989. Poor correlation between the levels of proteinase inhibitors found in seeds of different cultivars of cowpea (Vigna unguiculata) and the resistance/ susceptibility to predation by Callosobruchus maculatus. J. Agric. Food Chem. 27:1139-1143. 